\title{
Reconstructing the diet, trophic level, and migration pattern of Mysticete whales based on baleen isotopic composition.
}

Philip M. Riekenberg ${ }^{1 *}$, Jaime Camalich ${ }^{1}$, Elisabeth Svensson ${ }^{1}$, Lonneke L. IJsseldijk², Sophie M.J.M.

Brasseur $^{3}$, Rob Witbaard ${ }^{4}$, Mardik F. Leopold ${ }^{3}$, Elisa Bravo Rebolledo ${ }^{3,6}$, Jack J. Middelburg ${ }^{5}$, Marcel T.J. van der Meer ${ }^{1}$, Jaap S. Sinninghe Damsté ${ }^{1,5}$, Stefan Schouten ${ }^{1,5}$

(1) Department of Marine Microbiology \& Biogeochemistry, NIOZ Royal Netherlands Institute for Sea Research, and Utrecht University, PO Box 59, Den Hoorn, 1790AB, The Netherlands

(2) Department of Pathobiology, Faculty of Veterinary Medicine, Utrecht University, Yalelaan 1, 3854

CL, Utrecht, The Netherlands

(3) Wageningen Marine Research, Wageningen University and Research, PO Box 57, 1780 AB, Den

Helder, The Netherlands

(4) Department of Estuarine and Delta Systems, NIOZ Royal Netherlands Institute for Sea Research, and Utrecht University, PO Box 140, 4400 AC, Yerseke, The Netherlands

(5) Department of Earth Sciences, Faculty of Geosciences, Utrecht University, Princetonlaan 8a, 3584 CB, Utrecht, The Netherlands

(6) Current: Bureau Waardenburg, Department of Bird Ecology, 4101 CK Culemborg, The Netherlands

Key words: fasting, compound specific, temporal, migration 


\section{Abstract}

2 Baleen from mysticete whales is a well-preserved proteinaceous material that can be used to identify

3 migrations and feeding habits for species whose migration pathways are unknown. Analysis of $\delta^{13} \mathrm{C}$ and

$4 \quad \delta^{15} \mathrm{~N}$ from bulk baleen has been used to infer migration patterns for individuals. However, this approach

5 has fallen short of identifying migrations between regions as it is difficult to determine variations in

6 isotopic shifts without temporal sampling of prey items. Here we apply analysis of $\delta^{15} \mathrm{~N}$ values of amino

7 acids to five baleen plates belonging to three species, revealing novel insights on trophic position,

8 metabolic state, and migration between regions. Humpback and minke whales had higher reconstructed

9 trophic levels than fin whales (3.4-3.5 versus 2.7-2.9, respectively) as expected due to different feeding

10 specialization. Isotopic niche areas between baleen minima and maxima were well separated, indicating

11 regional resource use for individuals during migration that aligned with isotopic gradients in Atlantic

12 Ocean particulate organic matter. $\delta^{15} \mathrm{~N}$ values from phenylalanine confirmed regional separation between

13 the niche areas for two fin whales as migrations occurred and elevated glycine and threonine $\delta^{15} \mathrm{~N}$ values

14 revealed physiological changes due to fasting. Simultaneous resolution of trophic level and physiological

15 changes allow for identification of regional migrations in mysticetes. 


\section{Introduction}

17 Mysticete whales are a concern for ecosystem based management after their populations were decimated

18 by whaling $(1,2)$. Despite their current protected status, many details of the migratory patterns and

19 feeding ecology of individual mysticetes remains uncertain and limited to a broader understanding of

20 population scale patterns. This is especially true at the level of metapopulations and any additional

21 information on ecological niche separation may help to inform policy makers to protect key habitats (3).

22 New tools are now used to unravel migrations of mysticete whales, such as retrospective analysis of

23 historical landing data $(1,4)$ and satellite tags to track both migratory paths and feeding strategies (5-9).

24 However, tags provide only a small observational time window and are difficult to successfully deploy

25 due to the mobility and lifestyle of these animals (10).

26 Feeding strategy and trophic ecology of mysticetes have primarily been identified through visual

27 confirmation during feeding or stomach content analysis from strandings and historic catch data $(11,12)$.

28 However, prey in the stomach of deceased animals only represent the animal's last meal with the presence

29 and the content (13) depending on the health status of the animal prior to death (i.e. trophic downgrading

30 due to sickness). In contrast, proteinaceous materials that are continually produced across an animal's

31 lifetime (e.g. baleen, earplugs) provide a continuous record of metabolic processes $(14,15)$ and dietary

32 composition across the time period that they have been produced and are thus useful in identifying prey

33 composition and feeding strategies over a long period prior to death $(16,17)$. As a metabolically inert

34 tissue, the incremental deposition of baleen faithfully records the dietary composition of the animal from

35 when it is deposited until it is either lost or worn away. Baleen is composed almost entirely of keratin

36 derived from metabolites of the bloodstream (18) and captures a long term record of the animal's blood

37 protein during keratin synthesis (19). This is in contrast to erythrocytes or skin tissue that provide a single

38 integrated snapshot of isotopic composition across approximately one to two weeks to four months,

39 respectively, depending on turnover within the pool of carbon $(\mathrm{C})$ or nitrogen $(\mathrm{N})$ being examined and the

40 size of the animal (20). Whole lengths of baleen often reflect the dietary conditions from several months

41 to several years depending on their growth rate and sampling distance from the gums.

The isotopic composition of $\mathrm{C}$ and $\mathrm{N}$ in baleen protein (expressed as $\delta^{13} \mathrm{C}$ and $\delta^{15} \mathrm{~N}$ values, respectively) provides insights about the diet composition (10,21-23). Typically, consumers have higher

$44 \quad \delta^{13} \mathrm{C}$ and $\delta^{15} \mathrm{~N}$ values by $0.5-2 \%$ and $0.5-5 \%$, respectively compared to their diet in the system being

45 examined $(24,25)$. These enrichments, or trophic discrimination factors (TDFs), vary with species, tissue

46 type, metabolism, and diet quality and therefore require consideration of the available ecological context

47 when assigning a TDF to a species within an ecosystem $(26,27)$. Dietary estimates reconstructed using 
bulk isotopic values reflect a mixture of influencing factors and often provide results that are inconclusive or muddled (28). This is especially true in systems where the isotopic baseline supporting production changes or the trophic level that animals feed at have shifted $(29,30)$. The $\delta^{15} \mathrm{~N}$ values of resources supporting primary production can shift substantially, both spatially and temporally, depending on the balance of biogeochemical processes affecting available $\mathrm{N}$ sources $\left(\mathrm{NO}_{3}{ }^{-}, \mathrm{NO}_{2}{ }^{-} \mathrm{NH}_{4}{ }^{+}, \mathrm{N}_{2}\right)$ within an ecosystem (31-34). This occurs, for example, with wide ranging mysticetes in the north Atlantic Ocean where considerably higher $\delta^{15} \mathrm{~N}$ values are observed for particulate organic matter (POM) in the higher latitudes $\left(>70^{\circ} \mathrm{N}, 6\right.$ to $10 \%$ o) compared to lower mid-Atlantic areas $\left(10^{\circ} \mathrm{N},-1\right.$ to $1 \%$; (35). These shifts in baseline $\delta^{15} \mathrm{~N}$ values are expected to interfere with estimates of trophic level for North Atlantic mysticetes as they migrate between mid-Atlantic breeding grounds and high-latitude feeding grounds. Correction for this baseline shift would usually require extensive sampling of primary consumers across both regions (24, 36).

The issue depicted above may be resolved by compound specific analysis of the $\delta^{15} \mathrm{~N}$ values of amino acids contained in baleen. Isotopic differences that arise due to metabolic pathway differences between amino acid types can help to address regional shifts caused by the underlying $\delta^{15} \mathrm{~N}$ baseline by providing simultaneous temporal information on trophic level and baseline $\delta^{15} \mathrm{~N}$ values supporting the consumer (37-39). Baseline isotopic values are provided by source amino acids that undergo little change as they are metabolized (e.g. phenylalanine (Phe), methionine, tyrosine, and lysine; (40, 41). Additionally, trophic amino acids undergo considerable fractionation as they are metabolized (glutamic acid (Glu), aspartic acid, alanine, isoleucine, leucine, proline, and valine) and so-called 'metabolic' amino acids that undergo variable fractionations depending on the animal's physiology or dietary composition (glycine (Gly), threonine (Thr)). Through the utilization of both source and trophic amino acids, a trophic discrimination factor (TDF) (38), and $\beta$, the difference between trophic and source amino acids in the underlying primary producers, trophic level estimates for individuals can be calculated. Trophic level estimates inherently integrate underlying baseline shifts that have occurred during migrations between breeding and feeding grounds. Uncertainties remain about the effects of diet quality and metabolic effects associated with routing of compounds (i.e. higher fractionation associated with poorer assimilation efficiency) or excretion pathways (i.e. excretion of urea versus ammonia), but these are incorporated into the high level of uncertainty assigned to the TDF $(7.6 \pm 1.5 \%$; (40) and resulting trophic level estimates.

In this study we are among the first to combine bulk stable isotope with analysis of $\delta^{15} \mathrm{~N}$ in amino acids from baleen sourced from stranded or bowcaught fin whales ( $\mathrm{n}=3$, Balaenoptera physalus), a stranded humpback whale (Megaptera novaeangliae), and a minke whale (Balaenoptera acutorostrata), all opportunistically sampled in the Netherlands. $\delta^{15} \mathrm{~N}$ values of amino acids from baleen allows for 
81 resolution of trophic effects from changing regional $\delta^{15} \mathrm{~N}$ values and characterization of potential

82 metabolic effects from fasting and episodic feeding. Additionally, we provide evidence of feeding in

83 different regions due to migration between Mid-Atlantic breeding and high-latitude feeding areas through

84 application of isotopic niche areas from trophic level corrected bulk isotope data from baleen.

\section{Methods}

\section{Sample collection}

87 Baleen plates were collected from dead mysticetes that stranded on the Dutch coast or brought into Dutch

88 harbors caught on a ship's bow in 2012 and 2013 (Table 1). Baleen from three fin whales were acquired

89 from the faculty of Veterinary Medicine of Utrecht University, the baleen from the humpback whale

90 (Megaptera novaeangliae) was acquired from Naturalis Biodiversity Center, Leiden, and the minke whale

91 (Balaenoptera acutorostrata) baleen was acquired from a private collection.

\section{Sample preparation}

93 One baleen plate per individual whale was air dried ( $>2$ days), cleaned with bidistilled water, then

94 dichloromethane, and dried at $40^{\circ} \mathrm{C}$ for $\sim 10$ hours. Powdered keratin was collected using a hand drill (3

$95 \mathrm{~mm}$ bit) along the leg (labial side) of the plate at either $0.5 \mathrm{~cm}$ or $1 \mathrm{~cm}$ intervals (representing a range of

$96 \sim 2$ to 4 weeks of growth between samplings) depending on the relative size of the plate, from the gingiva

97 along the full length of the main plate. Powdered baleen was collected and stored at $-20^{\circ} \mathrm{C}$ until further

98 processing. Since baleen grows continuously throughout a whale's life the material closest to the gingiva

99 reflects the most recently produced layer with the material farther away from the gums reflecting

100 increasingly older periods of the whale's foraging history. Subsampled material (3-5 mg) for analysis of

$101 \delta^{15} \mathrm{~N}$ of amino acids were selected based on the variation within the bulk $\delta^{15} \mathrm{~N}$ values observed for each

102 individual and target minimum and maximum values observed across the lengths of plate.

103 Bulk stable isotope analysis

104 Approximately $0.5-0.8 \mathrm{mg}$ of dry, homogenized keratin powder was weighed into tin cups in duplicates

105 for determination of carbon $\left(\delta^{13} \mathrm{C}\right)$ and nitrogen $\left(\delta^{15} \mathrm{~N}\right)$ isotopic ratios for bulk material, as well as carbon

106 and nitrogen content (\%) of bulk biomass. Samples were analyzed on a Flash 200 elemental analyzer

107 coupled to a Delta V Advantage isotope ratio mass spectrometry (Thermo scientific, Bremen).

108 Stable isotope ratios are expressed using the $\delta$ notation in units per mil:

$$
\delta(\% \text { o })=\left(\left(\mathrm{R}_{\text {sample }} / \mathrm{R}_{\text {standard }}\right)-1\right) \times 1000 \text {, where } \mathrm{R}={ }^{13} \mathrm{C} /{ }^{12} \mathrm{C} \text { or }{ }^{15} \mathrm{~N} /{ }^{14} \mathrm{~N} \quad \text { Equation } 1
$$


and expressed versus Vienna Pee Dee Belemnite (VPDB) for $\delta^{13} \mathrm{C}$ and atmospheric $\mathrm{N}_{2}$ (air) for $\delta^{15} \mathrm{~N}$. A

laboratory acetanilide standard with $\delta^{13} \mathrm{C}$ and $\delta^{15} \mathrm{~N}$ values calibrated against NBS-22 and IAEA-N1, standards (urea, casein) for $\delta^{13} \mathrm{C}$ and $\delta^{15} \mathrm{~N}$ analyses were $0.18 \%$ and $0.2 \%$, respectively.

\section{Amino acid sample preparation}

114 The method is a modified version of the amino acid analysis method by Chikaraishi et al. (2007) as described in Riekenberg, van der Meer (42). In short, samples were hydrolyzed, derivatized into Npivaloyl/isopropyl (NPiP) derivatives and analyzed in duplicate with a Trace 1310 gas chromatograph coupled to a Delta V Advantage isotope ratio mass spectrometer (Thermo Scientific, Bremen) via an IsoLink II. Details about the temperature ramp, program settings, and normalization procedures are provided in (42). We report $\delta^{15} \mathrm{~N}$ values for 12 amino acids including alanine, aspartic acid, Glu, Gly, isoleucine, leucine, lysine, Phe, serine, Thr, tyrosine, and valine. The precision for samples and standards was $<0.5 \%$ for all amino acids across the 14 sequences that comprise this data set.

\section{Estimating growth intervals}

123 To examine the relative rates of change for the oscillations in the $\delta^{15} \mathrm{~N}$ values for bulk material along the length of the main plate, we fitted a generalized additive model (GAM) for each individual. GAM models were produced using the geom_smooth function in the ggplot2 package with model= "gam" to apply smoothing parameters selected by data driven methods using Akaike information criteria to time series in $\mathrm{R}$ (v4.0.0) with R Studio (v1.1.463) (17, 43). Oscillations within $\delta^{13} \mathrm{C}$ values for individuals were less distinct, having a smaller range than those for $\delta^{15} \mathrm{~N}$ values often due to closer similarity in prey $\delta^{13} \mathrm{C}$ values and are known to be further confounded due to coastal foraging in areas with gradients in $\delta^{13} \mathrm{C}(17)$. Therefore, $\delta^{15} \mathrm{~N}$ values were used to estimate baleen growth rates for each individual by assuming the oscillation between sequential $\delta^{15} \mathrm{~N}$ value minima along the baleen record represented migratory annual movements between foraging grounds. Growth estimates were determined as the distance between sequential minimum $\delta^{15} \mathrm{~N}$ values and this interval was used to estimate a weekly growth rate as in Busquets-Vass, Newsome (17). To further clarify the midpoint between minimum and maximum periods for $\delta^{15} \mathrm{~N}$ values we plotted a linear regression across $\delta^{15} \mathrm{~N}$ values for each baleen and binned regions of each baleen into minimum (below midpoint) and maximum (above midpoint) values depending on relative position to the conditional mean to allow for further analysis of regional differences for $\delta^{15} \mathrm{~N}$ values. 
139 Trophic level estimated from baleen amino acids are presented using weighted averages for both source

140 and trophic amino acids presented in Chikaraishi, Ogawa (40) modified with a tissue specific TDF

141 previously estimated for blue whales (Balaenoptera musculus) in Busquets-Vass, Newsome (17).

142 Trophic level $=\left(\delta^{15} \mathrm{~N}_{\Sigma \text { trophic }}-\delta^{15} \mathrm{~N}_{\Sigma \text { source }}-\beta\right) / \mathrm{TDF}+1$

Equation 2

143 where $\delta^{15} \mathrm{~N}_{\Sigma \text { trophic }}$ and $\delta^{15} \mathrm{~N}_{\Sigma \text { source }}$ are the weighted mean values for grouped trophic (alanine, aspartic acid,

144 glutamic acid, isoleucine, leucine, and valine) and source (lysine and phenylalanine) amino acids,

145 respectively, $\beta$, the \% difference between Glu and Phe in the underlying phytoplankton is assumed to be

$1463.4 \%$, and a TDF of $4 \%$ accounting for the discrimination in trophic amino acids between the baleen

147 whales and their diet. The TDF of $4 \%$ has been scaled from the $1.8 \%$ o trophic enrichment factor estimated

148 for $\delta^{15} \mathrm{~N}$ for bulk material from B. musculus baleen (17) assuming scaling factors of 3.4\%o and 7.6\% for

149 trophic discrimination factors for bulk and amino acid trophic level determination, respectively. Error

150 propagation for trophic level gives a standard deviation of \pm 0.8 using the equation presented in Ohkouchi,

151 Chikaraishi (39).

152 Correction for trophic enrichment to establish baseline estimates for $\delta^{15} \mathrm{~N}$ using phenylalanine were 153 calculated as

$154 \quad \delta^{15} \mathrm{~N}_{\text {Phe-Base }}=\delta^{15} \mathrm{~N}_{\text {Phe }}-(0.4 *($ trophic level-1) $)$

Equation 3

155

156

157

158

159

160

161

162

163

164

165

166

where $0.4 \%$ is the small enrichment observed for Phe during metabolism (40) and trophic level calculated for each individual (Table 1).

Trophic level estimates were further used to estimate baseline $\delta^{13} \mathrm{C}$ and $\delta^{15} \mathrm{~N}$ values for bulk measurements using the equations:

$\delta^{13} \mathrm{C}_{\text {Base }}=\delta^{13} \mathrm{C}_{\text {Bulk }}-[2.26+(0.5 *($ trophic level- 2$))]$

Equation 4

$\delta^{15} \mathrm{~N}_{\text {Base }}=\delta^{15} \mathrm{~N}_{\text {Bulk }}-[2.77+(2.2 *($ trophic level- -2$))]$

Equation 5

where $\delta^{13} \mathrm{C}_{\text {Bulk }}$ and $\delta^{15} \mathrm{~N}_{\text {Bulk }}$ represent the $\mathrm{C}$ and $\mathrm{N}$ isotopic composition of bulk material, 2.26\%o and 2.77\%o represent the offset between diet and baleen for carbon and nitrogen (44), 0.5\%o and 2.2\%o represent the offsets for trophic enrichment for carbon and nitrogen for the trophic levels supporting the whales prey (25), and trophic level is the average estimate for each individual (Table 1). Wilcoxon signed rank t-tests were used to examine individual amino acid $\delta^{15} \mathrm{~N}$ values between regions of baleen.

Niche modeling 
To analyze differences in isotopic niches within each individual baleen, standard ellipse areas corrected for their sample size $\left(\mathrm{SEA}_{\mathrm{c}}\right.$ ) were constructed containing $70 \%$ of the variation in each group for the binned minimum and maximum values for $\delta^{13} \mathrm{C}_{\text {Base }}$ vs $\delta^{15} \mathrm{~N}_{\text {Base }}$ for each individual using the SIBER package (45). The overlap between groups was characterized through calculation of the Euclidean distance between the centroids for both minimum and maximum $\mathrm{SEA}_{c}$, followed by a residual permutation and Hotelling $\mathrm{T}^{2}$ -

172 test to evaluate statistical differences $(46,47)$ between the areal coverage of the two niches $(\alpha=0.05)$ using 173 the package 'Hotelling'.

\section{Results}

175 Bulk $\delta^{13} C$ and $\delta^{15} N$ values

176 The $\delta^{13} \mathrm{C}$ values for all individuals fell within the range of -17.5 to $-20 \%$ across all baleens, with 177 oscillations of 0.5 to $1.5 \%$ that generally mirrored changes observed in $\delta^{15} \mathrm{~N}$ values, with some deviations

178 (Fig. 1, Supplemental Table 1). $\delta^{13} \mathrm{C}$ values for the fin whales were similar among individuals and higher $179(-18.9$ to $-19.2 \%$ ) than for the humpback whale $(-19.6 \%)$, but lower than for the minke whale $(-18.1 \%$; one-way ANOVA: $\left.\mathrm{F}_{4,252}=77, p<0.001\right)$. Within-individual variation in $\delta^{15} \mathrm{~N}$ values was larger than seen for $\delta^{13} \mathrm{C}$ values (maximum within-individual range in $\delta^{15} \mathrm{~N}$ is 11.2 to $14.8 \%$ in the humpback whale). Oscillations in $\delta^{15} \mathrm{~N}$ values also showed greater amplitude from 0.5 to $\sim 3 \%$, with median values for the humpback and minke plates (12.8\% and $12.2 \%$ ) higher than those for all three fin whale plates (9.3 to 10\%: Supplementary Table 1). $\delta^{15} \mathrm{~N}$ values were higher for both the minke and humpback whale (11.8 and $12.8 \%$, respectively; one-way ANOVA: $\left.\mathrm{F}_{4,252}=238, p<0.001\right)$ than for the fin whales $(9.2$ to $10 \%$ ).

The three fin whales (FW1, FW2, FW3, Fig. 2) displayed regular oscillations in $\delta^{15} \mathrm{~N}$ values that imply baleen growth rates of 2-3.5 $\mathrm{mm}^{-1} \mathrm{we}^{-1}$, calculated based on GAM modelling (Table 2), following the approach of Aguilar, Giménez (48). The minke whale (MN, Fig. 2) showed less regular minima that corresponded to a growth rate of $2.3 \mathrm{~mm}^{\text {week }}{ }^{-1}$, while the humpback whale displayed no distinct $\delta^{15} \mathrm{~N}$ minima but rather a continuous decrease in $\delta^{15} \mathrm{~N}$ value from the gingiva across the full length of baleen (from 14.8 to $11.6 \%$; HB, Fig. 2) with slight oscillations from which no growth estimate could be reasonably estimated. Linear regressions applied to the $\delta^{15} \mathrm{~N}$ values for bulk baleen indicated regions in the baleen that were above (black) and below (gray) the conditional mean (Fig. 2). The minimum and maximum periods of these oscillations reflect the net effects from metabolism, trophic position, and the underlying values of the resources being utilized during each individual's migrations. Minimum and maximum periods for $\delta^{15} \mathrm{~N}$ values (grey and black bars, Fig. 2) are thought to reflect residence times in 
reflecting the net effects from different migrations that occurred within an individual's lifetime and the seasonal decrease in the excretion of ${ }^{15} \mathrm{~N}$ in urine as fasting occurs $(48,49)$. These minimum and maximum periods were utilized to target amino acid $\delta^{15} \mathrm{~N}$ samples (hash marks Fig. 2) in order to maximize the potential differences between samplings in each period.

$\delta^{15} \mathrm{~N}$ of amino acids

Trophic levels were estimated using the weighted means of the $\delta^{15} \mathrm{~N}$ values for trophic and source amino acids (see methods Eq. 2) with means ranging from 2.7 to 2.9 for the fin whales, 3.4 for the humpback whale, and 3.5 for the minke whale (Fig. 3A). The trophic level estimates did not vary significantly (twoway ANOVA, all $p>0.05$ ) between the minimum and maximum periods examined along the baleen. Therefore, single trophic level estimates from the average for each individual whale were utilized for trophic level corrections applied in the calculations for baseline corrected $\delta^{13} \mathrm{C}$ and $\delta^{15} \mathrm{~N}$ values $\left(\delta^{13} \mathrm{C}_{\text {Base }}\right.$ and $\delta^{15} \mathrm{~N}_{\text {Base }}$; Eq 2; Table 2). This correction is also applied to Phe to reduce $\delta^{15} \mathrm{~N}$ values representing the calculated value supporting the base of the food web ( $\left.\delta^{15} \mathrm{~N}_{\text {Phe-Base }}\right)$ by correcting for fractionation due to trophic levels using the measured TL estimate (Eq. 3). Changes in the $\delta^{15} \mathrm{~N}_{\text {Phe-Base }}$ values reflect the were found to be significantly different between individuals and between minimum and maximum $\delta^{15} \mathrm{~N}$ value periods (two-way ANOVA: Individuals, $\mathrm{F}_{4,54}=5.3, p=0.001 ; \min / \max \mathrm{F}_{1,54}=11.4, p=0.001$; periods for bulk $\delta^{15} \mathrm{~N}$ values than in the minimum periods (Wilcoxon ranked t-test, $\mathrm{Z}_{8}=-2.5, p=0.008$ ). minimum periods $\left(\mathrm{Z}_{5}=-1.9, p=0.06\right)$, but not statistically significant using a threshold of $\alpha=0.05$ (Fig $3 b$ ).

Thr and Gly are both metabolic amino acids that provide indications for diet composition and fasting state of the individuals, respectively $(50,51) . \delta^{15} \mathrm{~N}$ values of Phe were subtracted from both Thr and Gly $\delta^{15} \mathrm{~N}$ values to correct metabolic AA $\delta^{15} \mathrm{~N}$ values for changes resulting from baseline values (Fig $4 \mathrm{a} \& \mathrm{~b}$ ). $\delta^{15} \mathrm{~N}_{\text {Thr }}$ values were not significantly different when examined between minimum and maximum periods for bulk $\delta^{15} \mathrm{~N}$ values (two- way ANOVA, all $p>0.05$ ), but were found to be generally higher for the fin whales (one-way ANOVA: $\mathrm{F}_{4,53}=6.8, p<0.001$; Fig. 4a) with a wider range (-29.3 to $-11.2 \%$ ) than for the humpback whale (-28.4 to $-25.9 \%$ ) and minke whale (-32.3 to $-21.6 \%$ ). $\delta^{15} \mathrm{~N}_{\text {Gly }}$ values were significantly different between minimum and maximum periods for individuals (two-way ANOVA: Individuals F4,50= $112, p<0.001 ; \min / \max \mathrm{F}_{1,50}=23.9, p<0.001$ ). For all individuals, the means for the minimum periods were higher than for the maximum, but was only statistically higher for FW3 ( $\left.\mathrm{Z}_{8}=2, p=0.04\right)$, although 


\section{Isotopic niche overlap within individuals}

232 Isotopic niche areas (SEAc) were calculated by applying a Bayesian statistical model (SIBER package) to

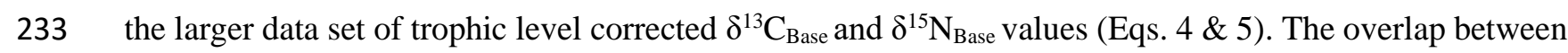

234 the minimum and maximum baleen periods ranged from 0 (implying different values for basal resources)

235 to $56 \%$ (indicating some overlap) with Hotelling's T² -test, indicating significant differences between

236 periods for all individuals (Fig. 5). Separation of SEAc areas for periods predominately occurred along the $237 \mathrm{y}$ axis $\left(\delta^{15} \mathrm{~N}_{\text {Base }}\right)$ for all individuals besides $\mathrm{HB}$, where separation occurred across the $\mathrm{x}$ axis $\left(\delta^{13} \mathrm{C}_{\text {Base }}\right)$.

\section{Discussion}

\section{Growth Rates for Baleen}

240 The marked oscillations in $\delta^{15} \mathrm{~N}$ values of baleen are assumed to reflect residence times in Mid-Atlantic 241 breeding grounds (minima) and high-latitude feeding grounds (maxima) with substantial differences in the 242 underlying $\delta^{15} \mathrm{~N}$ values for POM in these regions (-1 to $1 \%$ versus 6-10\%, respectively) and differences in 243 excretion of $\delta^{15} \mathrm{~N}$ depending on fasting status during migrations $(48,49)$. The changes in amplitude of the 244 oscillations in baleen reflect resource use and feeding status during migrations that occurred within an 245 individual's lifetime. The humpback whale did not display readily apparent oscillations in $\delta^{15} \mathrm{~N}$ values, but 246 rather a distinct increase in $\delta^{15} \mathrm{~N}$ value that progressed along the length of baleen, suggesting different 247 migration behavior than observed for the other whales in this study. The estimates for baleen growth rates 248 for the 4 individuals with recurring minima in $\delta^{15} \mathrm{~N}_{\text {bulk }}$ values (FW1-3 \& MN; 10.4-16.3 cm y ${ }^{-1}$; Table 1) 249 agree with previous estimates from blue (17), minke $\left(12.9 \mathrm{~cm} \mathrm{y}^{-1},(52)\right)$ and bowhead whales (Balaena 250 mysticetus; 16-25 $\mathrm{cm} \mathrm{y}^{-1}$, (19)), all of which assume continuous growth across seasons. The length of 251 plates in this study are relatively short due to the availability of stranded and bow-caught animals 252 examined and represent a maximum of 3 years of migration (FW3, with $4 \delta^{15} \mathrm{~N}$ minima) within these 253 individuals. Other studies have examined considerably longer plates $(17,53,54)$.

\section{Trophic Levels}

255 Trophic level estimates from minimum and maximum regions of $\delta^{15} \mathrm{~N}$ values along the baleen are

256 expected to reflect the largest contrasts between food resources throughout the multi-year periods recorded 257 in the baleen. Trophic level estimates from amino acid $\delta^{15} \mathrm{~N}$ values indicated no significant changes in TLs 258 across the baleen records for these 5 individuals. Consistent trophic levels throughout migratory periods 259 reflect a more-or-less continuous utilization of the same kind of prey, without considerable periods of 260 specialization, e.g. a switching between fish and krill during migration. The reconstructed trophic levels were significantly lower (one-way ANOVA: $\mathrm{F}_{4,55}=11.7, p<0.001$ ) for the fin whales than for the 
262 humpback and minke whales. This is fully consistent with the fact that -fin whales preferentially consume

263 krill in areas where these are abundant and only occasionally feeding opportunistically on schools of small

264 fish when krill is scarce $(55,56)$. The higher reconstructed trophic levels for both humpback and minke

265 whales are expected as their foraging typically includes larger number of small fishes less than $30 \mathrm{~cm}$

266 length such as herring (Clupea harengus) and sprat (Sprattus sprattus) (57-59). Trophic level estimates

267 observed in the minimum and maximum regions of $\delta^{15} \mathrm{~N}$ values along the baleen are expected to reflect

268 the largest contrasts between food resources throughout the multi-year periods recorded in the plate.

269 Estimates calculated from amino acid $\delta^{15} \mathrm{~N}$ values indicated no significant changes in trophic levels across

270 the baleen records for these 5 individuals. Consistent trophic levels throughout migratory periods reflects a

271 more or less continuous utilization of the same prey, without considerable periods of specialization or

272 switching between smaller fishes and krill during migration and no major effect of seasonal variations in

$273{ }^{15} \mathrm{~N}$ excretion rates. Trophic level estimates for all of the whales (ranging from 2.7 to 3.5 ) were based on a

274 relatively small TDF (4\%o) compared to the typically applied 7.6\%o value (the difference between the

275 amino acids Glu and Phe in marine organisms, ((40)) for TDF $(38,41)$, but yield comparable trophic

276 levels as determined through stomach contents for other mysticete whales (60). The small TDF reflects the

277 increased similarity between the protein quality of the diet and the consumer, resulting in less reworking

278 and therefore less fractionation of amino acid $\mathrm{N}$ during metabolism $(38,61)$.

\section{Metabolism of whales}

280 The amino acids Gly and Thr have been found to respond to fasting and protein deficiency in mammals 281 through variable enrichments in $\delta^{15} \mathrm{~N}$ values for each AA $(50,51)$ as metabolism of stored lipid resources

282 occurs. The $\delta^{15} \mathrm{~N}$ values of glycogenic amino acids (Gly, serine, proline, and aspartic acid) are expected to

283 increase as exogenous material becomes limited and endogenous protein starts to be metabolized (62).

284 Fasting has been previously thought to occur as whales migrate southward out of their northern feeding

285 grounds towards breeding sites (63) and feeding becomes more confined to opportunistic feeding events

$286(48,53)$. Baseline-corrected $\delta^{15} \mathrm{~N}_{\text {Gly }}$ values were statistically higher in the minimum periods for bulk $\delta^{15} \mathrm{~N}$

287 values than in the maximum periods for bulk $\delta^{15} \mathrm{~N}$ in FW3 (Fig. 4b), although all five individuals had

288 higher averages for minimum periods ranging from 0.3 to $1.4 \%$ and the difference for FW2 was nearly

289 statistically significant ( $p=0.06$ ). These isotopic enrichments for $\delta^{15} \mathrm{~N}$ are lower than the observed shift (2-

$2906 \%$ ) in glycogenic amino acids for fasting southern elephant seals (Mirounga leonina, Lübcker,

291 Whiteman (50)). This suggests that the impacts from fasting on glycogenic $\delta^{15} \mathrm{~N}$ values for mysticetes may

292 be more limited than during breeding and molting events in other marine mammals. This smaller observed

293 effect may be due to either the considerable body size and lipid stores or through subsistence with

294 opportunistic feeding offsetting more extreme fasting effects (64). Although limited in scale, isotopic 
enrichment of the $\delta^{15} \mathrm{~N}_{\mathrm{Gly}}$ values onset in the same manner (during minimum periods) across all individuals regardless of species (Fig. 4b) and suggests that there is a fasting effect that occurs as fat stores are accessed during migrations towards breeding grounds when feeding becomes opportunistic.

Higher $\delta^{15} \mathrm{~N}_{\text {Thr }}$ values in mammals have been observed to coincide with reduced protein quality in their starvation (51) although this mechanism is incompletely characterized. Extremely low values for $\delta^{15} \mathrm{~N}_{\text {Thr }}$ patterns of consistently low values $(-27.4 \pm 0.7 \%$ and $-28.2 \pm 3.2 \%$, respectively; Fig $4 a)$ that are expected for adequate protein availability throughout the period of baleen examined. However, the fin whales (FW1-3) had higher $\delta^{15} \mathrm{~N}_{\text {Thr }}$ values (-22.1 to -20.6\%o) and larger ranges (3.7\%o to $7.4 \%$ ) due to higher $\delta^{15} \mathrm{~N}$ values (-15 to $-11 \%$ ) for Thr occurring intermittently throughout the baleen records. These higher values are potentially the result of protein deficiency and may mark protein deficiency or starvation events across an individual's lifetime. This finding conflicts with decreased $\delta^{15} \mathrm{~N}_{\text {Thr }}$ values observed in elephant seal whiskers during fasting (50), suggesting that there may be multiple effects impacting the metabolism of Thr during fasts that are more or less severe and warrant further investigation. There was no strong correlation between minimum and maximum periods for bulk $\delta^{15} \mathrm{~N}$ values in the baleen and differences in $\delta^{15} \mathrm{~N}_{\mathrm{Thr}}$ suggest more episodic onset than the more regularly occurring fasting effects observed for $\delta^{15} \mathrm{~N}_{\text {Gly }}$. Given these observations, the fin whales appear to have been more regularly under food stress than either the humpback or minke whale individuals examined in this study.

\section{Resource utilization}

315 Minimum and maximum periods in baleen bulk $\delta^{15} \mathrm{~N}$ values had distinct values for both $\delta^{15} \mathrm{~N}_{\text {Phe-Base }}$ (Fig.

$3163 \mathrm{~B}$ ) and the isotope niches formed using the wider data set of $\delta^{13} \mathrm{C}_{\text {Base }}$ and $\delta^{15} \mathrm{~N}_{\text {Base }}$ (eq. $4 \&$ 5; Fig. 5).

317 Distinct differences between the minimum and maximum bulk $\delta^{15} \mathrm{~N}$ periods likely reflect underlying

318 isotopic differences in resource values supporting the food web between Mid-Atlantic breeding grounds and high-latitude feeding grounds. Although few individuals have been tracked, all three species have been observed to make southerly winter migrations away from high-latitude feeding grounds $\left(>70^{\circ} \mathrm{N}\right)$ with North Atlantic fin whales having been observed to migrate to the Azores (8), humpback whales as far south as the Antillean islands (66), and minke whales observed off the east coast of Florida (67). These

323 large geographic separations between breeding and feeding grounds coincide with distinct underlying

324 isotopic values for POM in those regions. Isoscapes, i.e. geographic maps of the underlying yearly

325 averages for regional isotopic values of carbon and nitrogen $(35,68)$, characterize isotopic ranges for the

326 POM sampled from both the mid-Atlantic $\left(\delta^{13} \mathrm{C}-28\right.$ to $-30 \% ; \delta^{15} \mathrm{~N}-1$ to $1 \%$ ) and high-latitude Arctic $327\left(\delta^{13} \mathrm{C}-24\right.$ to $-20 \% ; \delta^{15} \mathrm{~N} 6$ to $\left.10 \%\right)$. The $\delta^{13} \mathrm{C}$ and $\delta^{15} \mathrm{~N}$ values from these regions vary depending on local 
biogeochemical processes (e.g. lower $\delta^{15} \mathrm{~N}$ values associated with oligotrophic conditions) and serve as variable end members for the source amino acids incorporated into baleen as it is produced from bloodstream metabolites derived from the animal's diet. The variations in those values are likely to be dampened and reflect the relative feeding intensity (opportunistic feeding in transit), variations in seasonal values for underlying biogeochemical processes, and the relative turnover of the internal source AA pool during migration and breeding. The ranges in $\delta^{15} \mathrm{~N}_{\text {Phe-Base }}\left(1.8\right.$ to $9.9 \%$ ), $\delta^{13} \mathrm{C}_{\text {Base }}(-20.6$ to $-22.9 \%$ ), and $\delta^{15} \mathrm{~N}_{\text {Base }}(2.3$ to $8.9 \%$ ) values all fall within the ranges expected for dietary intake of resources sourced from regions with distinct baseline isoscape values.

The larger ranges observed for $\delta^{15} \mathrm{~N}_{\text {Phe }}$ and $\delta^{15} \mathrm{~N}_{\text {Base }}$ (8.1 and 6.6, respectively) versus $\delta^{13} \mathrm{C}_{\text {Base }}(2.3 \%$ ) are likely due to increased turnover in $\mathrm{N}$ when compared to $\mathrm{C}$ within tissues as incidental feeding occurs (Trueman et al. 2019). N from incidental feeding is likely to be directly metabolized into animal tissues, while carbon can be metabolically routed to either direct incorporation to tissue or to storage within large lipid stores depending on feeding status (69). Under fasting conditions, lipid stores will be utilized as a source of $\mathrm{C}$ with a light $\delta^{13} \mathrm{C}$ value that reflects the fractionation of $\mathrm{C}$ from food resources containing the regional $\delta^{15} \mathrm{~N}$ values where they were consumed (70). These lipid stores are expected to be mobilized during times of limited feeding and reduce the impact of $\mathrm{C}$ derived from incidental feeding on $\delta^{13} \mathrm{C}_{\text {Base }}$ values of the baleen during fasting conditions as metabolites from blood are incorporated into baleen. This metabolic routing of $\mathrm{C}$ would contribute to masking the variation in $\mathrm{C}$ values along the baleen from incidental feeding. $\delta^{15} \mathrm{~N}_{\text {Base }}$ values (range of minimums from 2.8 to 5.8\%o) never reach the expected low

347 isoscape values for the mid-Atlantic of $\sim-1$ to $1 \%$ as the lower concentrations of $\mathrm{N}$ from opportunistic

348 feeding may be insufficient to fully turnover the comparatively high $\delta^{15} \mathrm{~N}$ fed on extensively at higher 349 latitude feeding grounds (6 to $10 \%$.).

Differentiation between periods of migration is supported in four individuals (FW1-FW3, MN), with clear separation between niche areas for basal resources that predominantly separate along the $\delta^{15} \mathrm{~N}_{\text {Base }}$ axis (Overlap $<27 \%$, Hotelling's $T^{2}$-test, $p<0.001$; Fig. 5). The humpback whale appears to predominately separate along the $\delta^{13} \mathrm{C}_{\text {Base }}$ axis which may reflect utilization of benthic resources within coastal margins, a

354 lack of opportunistic feeding during migrations (17), or a relatively reduced latitudinal migration

355 indicative of a temperate feeding style where individuals preferably feed in the temperate zone and reduce 356 reliance on high- latitude feeding (53). The gradual increase in $\delta^{15} \mathrm{~N}$ value across the baleen record of the

357 humpback whale from around 11.5 to $15 \%$ likely reflects increased contribution of herring and other 358 small fish during feeding. High $\delta^{15} \mathrm{~N}_{\text {Gly }}$ values observed for the humpback ( $\sim \%$; Fig. $\left.4 \mathrm{~b}\right)$ also mirror what 359 is expected for coastal predation on small fish migrating from estuarine into coastal waters where elevated $360 \quad \delta^{15} \mathrm{~N}_{\mathrm{Gly}}$ values have been previously observed such as herring (42). 
In the above discussions it should be noted that individuals FW1 and FW3 have statistically relevant differences between $\delta^{15} \mathrm{~N}_{\text {Phe-Base }}$ and $\delta^{15} \mathrm{~N}_{\text {Gly }}$, were males, and the remaining three individuals were female. Females are likely to display different isotopic patterns for both $\mathrm{C}$ and $\mathrm{N}$ as they reproduce, as the result of gestation and lactation altering the partitioning of resources and resultant isotopic values (71). These effects remain unaccounted for in this analysis due to the limited knowledge of these individual's life histories as baleen was sampled from beaching and bow-catch events. Additionally, the use of isoscapes to provide yearly averages for underlying isotope values for POM ignores variability that is expected during seasonal changes, although examinations of this variance are increasingly common $(54,72)$. Seasonal and temporal isotopic variations can be quite large $(35,68)$, especially for arctic or near arctic waters where the bulk of mysticete feeding occurs, and should be further considered in future work.

\section{Conclusion}

372 This study utilizes isotope analysis of bulk material and amino acids to provide metabolic and trophic 373 context to the isotopic oscillations observed within whale baleen. Trophic level estimates from source and 374 trophic amino acids were higher for the humpback and minke whales than for the fin whales, which 375 corresponds to previous observations. Trophic level estimates using amino acids allow for the correction 376 of bulk stable isotope values from consumers to the underlying baseline values of the primary producers 377 supporting regional foodwebs. Isotopic niche areas constructed from these baseline values using periods 378 of minimum and maximum bulk $\delta^{15} \mathrm{~N}$ values further confirm distinct differences between maximum 379 periods that reflect feeding in high-latitude feeding grounds and minimum periods that reflect resources utilized from mid-Atlantic breeding grounds for these individuals. $\delta^{15} \mathrm{~N}$ values from Gly and Thr provided useful metabolic indicators across the baleen sequences. Gly had higher values that aligned with considerable time spent in breeding grounds where feeding is expected to become incidental and fasting is likely to occur. Differences in Thr occurred more episodically and indicate that food stress or starvation occurred more often in the fin whales in this study than in the humpback or minke whales. Analysis of $\delta^{15} \mathrm{~N}$ values for amino acids provided further context into the movements and metabolic condition for mysticete whales, information that is especially important in wide ranging, difficult to track, animals with threatened conservation status. 
391 We thank Jort Ossebaar, Monique Verweij, and Ronald von Bommel for technical support for this project.

392 Funding was provided through the project "Waddensleutels" funded by "Waddenfonds" (WF203930). We

393 thank Kees Camphuysen for the input provided during the conceptual stages of this work. Clive Trueman

394 provided considerable food for thought on the first draft of this manuscript and we are grateful for his

395 considered input and conversation during lockdown. 


\section{References}

397

398

399

400

401

402

403

404

405

406

407

408

409

410

411

412

413

414

415

416

417

418

419

420

421

422

423

424

425

426

427

428

429

430

431

432

433

434

435

436

437

438

439

440

441

1. Roman J, Palumbi SR. Whales before whaling in the north Atlantic. Science. 2003;301(5632):508-

10.

2. Ryan C, McHugh B, Trueman CN, Sabin R, Deaville R, Harrod C, Berrow SD, I OC. Stable isotope analysis of baleen reveals resource partitioning among sympatric rorquals and population structure in fin whales. Marine Ecology Progress Series. 2013;479:251-61.

3. Fernandez M, Yesson C, Gannier A, Miller PI, Azevedo JMN. A matter of timing: how temporal scale selection influences cetacean ecological niche modelling. Marine Ecology Progress Series. 2018;595:217-31.

4. Sigurjónsson J. On the life history and autecology of North Atlantic rorquals. Developments in marine biology. 4: Elsevier; 1995. p. 425-41.

5. Dalla Rosa L, Secchi ER, Maia YG, Zerbini AN, Heide-Jørgensen MP. Movements of satellitemonitored humpback whales on their feeding ground along the Antarctic Peninsula. Polar Biology. 2008;31(7):771-81.

6. Costa DP. The Secret Life of Marine Mammals: Novel Tools for Studying Their Behavior and Biology at Sea. Oceanography. 1993;6(3):120-8.

7. Bentaleb I, Martin C, Vrac M, Mate B, Mayzaud P, Siret D, de Stephanis R, Guinet C. Foraging ecology of Mediterranean fin whales in a changing environment elucidated by satellite tracking and baleen plate stable isotopes. Marine Ecology Progress Series. 2011;438 285-302:285-302.

8. Silva MA, Prieto R, Jonsen I, Baumgartner MF, Santos RS. North Atlantic Blue and Fin Whales Suspend Their Spring Migration to Forage in Middle Latitudes: Building up Energy Reserves for the Journey? Plos One. 2013;8(10).

9. Panigada S, Donovan GP, Druon J-N, Lauriano G, Pierantonio N, Pirotta E, Zanardelli M, Zerbini AN, di Sciara GN. Satellite tagging of Mediterranean fin whales: working towards the identification of critical habitats and the focussing of mitigation measures. Scientific Reports. 2017;7(1):3365.

10. Newsome SD, Clementz MT, Koch PL. Using stable isotope biogeochemistry to study marine mammal ecology. Marine Mammal Science. 2010;26(3):509-72.

11. Rebolledo EL, IJsseldijk LL, Solé L, Begeman L, De Vries S, Van Den Boom L, Carpizo JC, Leopold MF. Unorthodox sampling of a fin whale's (Balaenoptera physalus) diet yields several new mesopelagic prey species. Aquatic Mammals. 2016;42(4):417.

12. Kawamura A. A review of food of balaenopterid whales. Sci Rep Whales Res Inst. 1980;32:155-

97.

13. Santos M, Clarke M, Pierce GJ. Assessing the importance of cephalopods in the diets of marine mammals and other top predators: problems and solutions. Fisheries Research. 2001;52(1-2):121-39.

14. Hunt KE, Stimmelmayr R, George C, Hanns C, Suydam R, Brower H, Rolland RM. Baleen hormones: a novel tool for retrospective assessment of stress and reproduction in bowhead whales (Balaena mysticetus). Conservation physiology. 2014;2(1).

15. Trumble SJ, Robinson EM, Berman-Kowalewski M, Potter CW, Usenko S. Blue whale earplug reveals lifetime contaminant exposure and hormone profiles. Proceedings of the National Academy of Sciences. 2013;110(42):16922-6.

16. Bentaleb I, Martin C, Vrac M, Mate B, Mayzaud P, Siret D, de Stephanis R, Guinet C. Foraging ecology of Mediterranean fin whales in a changing environment elucidated by satellite -tracking and baleen plate stable isotopes. Marine Ecology Progress Series. 2011;438:285-302.

17. Busquets-Vass G, Newsome SD, Calambokidis J, Serra-Valente G, Jacobsen JK, Aguíñiga-García S, Gendron D. Estimating blue whale skin isotopic incorporation rates and baleen growth rates: Implications for assessing diet and movement patterns in mysticetes. PloS one. 2017;12(5):e0177880. 
18. Ekdale EG, Deméré TA, Berta A. Vascularization of the Gray Whale palate (Cetacea, Mysticeti,

Eschrichtius robustus): soft tissue evidence for an alveolar source of blood to baleen. The Anatomical Record. 2015;298(4):691-702.

445 19. Schell DM, Saupe SM, Haubenstock N. Bowhead whale (Balaena mysticetus) growth and feeding as estimated by $\delta 13 C$ techniques. Marine Biology. 1989;103(4):433-43.

20. Thomas SM, Crowther TW. Predicting rates of isotopic turnover across the animal kingdom: a synthesis of existing data. Journal of Animal Ecology. 2015;84(3):861-70. marine mammals. Canadian Journal of Fisheries and Aquatic Sciences. 1996;53(3):528-33. 22. Fry B. Food web structure on Georges Bank from stable C, N, and S isotopic compositions. Limnology and Oceanography. 1988;33(5):1182-90.

23. Minagawa $\mathrm{M}$, Wada $\mathrm{E}$. Stepwise enrichment of ${ }^{15} \mathrm{~N}$ along food chains: Further evidence and the relation between $\delta^{15} \mathrm{~N}$ and animal age. Geochimica et Cosmochimica Acta. 1984;48(5):1135-40. Ecology. 2002;83(3):703-18.

25. McCutchan JH, Lewis Jr WM, Kendall C, McGrath CC. Variation in trophic shift for stable isotope ratios of carbon, nitrogen, and sulfur. Oikos. 2003;102(2):378-90.

465 28. Fry B. Stable Isotope Ecology. New York: Springer; 2006. 308 p.

466 29. Dorado S, Rooker JR, Wissel B, Quigg A. Isotope baseline shifts in pelagic food webs of the Gulf of Mexico. Marine Ecology Progress Series. 2012;464:37-49.

26. Olive PJW, Pinnegar JK, Polunin NVC, Richards G, Welch R. Isotope trophic-step fractionation: a dynamic equilibrium model. Journal of Animal Ecology. 2003;72(4):608-17.

27. Phillips DL, Inger R, Bearhop S, Jackson AL, Moore JW, Parnell AC, Semmens BX, Ward EJ. Best practices for use of stable isotope mixing models in food-web studies. Canadian Journal of Zoology. 2014;92(10):823-35.

30. Johnson AC, Hobson KA, Lunn NJ, McGeachy D, Richardson ES, Derocher AE. Temporal and intrapopulation patterns in polar bear foraging ecology in western Hudson Bay. Marine Ecology Progress Series. 2019;619:187-99.

31. Altabet MA, Pilskaln C, Thunell R, Pride C, Sigman D, Chavez F, Francois R. The nitrogen isotope biogeochemistry of sinking particles from the margin of the Eastern North Pacific. Deep Sea Research Part I: Oceanographic Research Papers. 1999;46(4):655-79.

32. Altabet MA, Francois R. Nitrogen isotope biogeochemistry of the Antarctic Polar Frontal Zone at 170 W. Deep Sea Research Part II: Topical Studies in Oceanography. 2001;48(19-20):4247-73.

33. Altabet MA. Isotopic tracers of the marine nitrogen cycle: present and past. Marine organic matter: biomarkers, isotopes and DNA: Springer; 2006. p. 251-93.

34. Brandes JA, Devol AH, Deutsch C. New Developments in the Marine Nitrogen Cycle. Chemical Reviews. 2007;107(2):577-89.

35. Trueman CN, St John Glew K. Chapter 6 - Isotopic Tracking of Marine Animal Movement. In: Hobson KA, Wassenaar LI, editors. Tracking Animal Migration with Stable Isotopes (Second Edition): Academic Press; 2019. p. 137-72.

36. Quezada-Romegialli C, Jackson AL, Hayden B, Kahilainen KK, Lopes C, Harrod C. tRophicPosition, an $r$ package for the Bayesian estimation of trophic position from consumer stable isotope ratios. Methods in Ecology and Evolution. 2018;9(6):1592-9.

37. Chikaraishi Y, Kashiyama Y, Ogawa NO, Kitazato H, Ohkouchi N. Metabolic control of nitrogen isotope composition of amino acids in macroalgae and gastropods: Implications for aquatic food web 488 studies. Marine Ecology Progress Series. 2007;342:85-90. 
38. McMahon KW, McCarthy MD. Embracing variability in amino acid $\delta^{15} \mathrm{~N}$ fractionation: mechanisms, implications, and applications for trophic ecology. Ecosphere. 2016;7(12):e01511-n/a. 39. Ohkouchi N, Chikaraishi Y, Close HG, Fry B, Larsen T, Madigan DJ, McCarthy MD, McMahon KW, Nagata T, Naito YI, et al. Advances in the application of amino acid nitrogen isotopic analysis in ecological and biogeochemical studies. Organic Geochemistry. 2017;113:150-74.

40. Chikaraishi Y, Ogawa NO, Kashiyama Y, Takano Y, Suga H, Tomitani A, Miyashita H, Kitazato H, Ohkouchi N. Determination of aquatic food-web structure based on compound-specific nitrogen isotopic composition of amino acids. Limnology and Oceanography: Methods. 2009;7(11):740-50.

41. O'Connell TC. 'Trophic' and 'source' amino acids in trophic estimation: a likely metabolic explanation. Oecologia. 2017;184(2):317-26.

42. Riekenberg PM, van der Meer M, Schouten S. Practical considerations for improved reliability and precision during determination of $\delta^{15} \mathrm{~N}$ values in amino acids using a single combined oxidationreduction reactor. Rapid Communications in Mass Spectrometry. 2020;n/a(n/a).

43. Chuang YH, Mazumdar S, Park T, Tang G, Arena VC, Nicolich MJ. Generalized linear mixed models in time series studies of air pollution. Atmospheric Pollution Research. 2011;2(4):428-35.

44. Borrell A, Abad-Oliva N, Gómez-Campos E, Giménez J, Aguilar A. Discrimination of stable isotopes in fin whale tissues and application to diet assessment in cetaceans. Rapid Communications in Mass Spectrometry. 2012;26(14):1596-602.

45. Jackson AL, Inger R, Parnell AC, Bearhop S. Comparing isotopic niche widths among and within communities: SIBER - Stable Isotope Bayesian Ellipses in R. Journal of Animal Ecology. 2011;80(3):595602.

46. Turner TF, Collyer ML, Krabbenhoft TJ. A general hypothesis-testing framework for stable isotope ratios in ecological studies. Ecology. 2010;91(8):2227-33.

47. Conti-Jerpe IE, Thompson PD, Wong CWM, Oliveira NL, Duprey NN, Moynihan MA, Baker DM. Trophic strategy and bleaching resistance in reef-building corals. Science Advances. 2020;6(15):eaaz5443.

48. Aguilar A, Giménez J, Gómez-Campos E, Cardona L, Borrell A. $\delta^{15} \mathrm{~N}$ value does not reflect fasting in Mysticetes. PLOS ONE. 2014;9(3):e92288.

49. Matthews CJD, Ferguson SH. Seasonal foraging behaviour of Eastern Canada-West Greenland bowhead whales: an assessment of isotopic cycles along baleen. Marine Ecology Progress Series. 2015;522:269-86.

50. Lübcker N, Whiteman JP, Millar RP, de Bruyn PJN, Newsome SD. Fasting affects amino acid nitrogen isotope values: a new tool for identifying nitrogen balance of free-ranging mammals. Oecologia. 2020.

51. Fuller BT, Petzke KJ. The dietary protein paradox and threonine ${ }^{15} \mathrm{~N}$-depletion: Pyridoxal-5'phosphate enzyme activity as a mechanism for the $\delta^{15} \mathrm{~N}$ trophic level effect. Rapid Communications in Mass Spectrometry. 2017;31(8):705-18.

52. Mitani Y, Bando T, Takai N, Sakamoto W. Patterns of stable carbon and nitrogen isotopes in the baleen of common minke whale Balaenoptera acutorostrata from the western North Pacific. Fisheries Science. 2006;72(1):69-76.

53. Eisenmann P, Fry B, Holyoake C, Coughran D, Nicol S, Bengtson Nash S. Isotopic evidence of a wide spectrum of feeding strategies in Southern hemisphere humpback whale baleen records. PLOS ONE. 2016;11(5):e0156698.

54. Trueman CN, Jackson AL, Chadwick KS, Coombs EJ, Feyrer L, Magozzi S, Sabin RC, Cooper N. Combining simulation modeling and stable isotope analyses to reconstruct the last known movements of one of Nature's giants. PeerJ. 2019;7:e7912.

55. Vighi M, Borrell A, Aguilar A. Stable isotope analysis and fin whale subpopulation structure in the eastern North Atlantic. Marine Mammal Science. 2016;32(2):535-51. 
56. Ryan C, Berrow SD, McHugh B, O'Donnell C, Trueman CN, O'Connor I. Prey preferences of sympatric fin (Balaenoptera physalus) and humpback (Megaptera novaeangliae) whales revealed by stable isotope mixing models. Marine Mammal Science. 2014;30(1):242-58.

57. Witteveen BH, Foy RJ, Wynne KM, Tremblay Y. Investigation of foraging habits and prey selection

541 by humpback whales (Megaptera novaeangliae) using acoustic tags and concurrent fish surveys. Marine Mammal Science. 2008;24(3):516-34.

58. Olsen E, Holst JC. A note on common minke whale (Balaenoptera acutorostrata) diets in the Norwegian Sea and the North Sea. Journal of Cetacean Research and Management. 2001;3(2):179-84.

59. Skaug HJ, Gjøsæter H, Haug T, Lindstrøm U, Nilssen K. Do minke whales (Balaenoptera acutorostrata) exhibit particular prey preferences. Journal of Northwest Atlantic Fishery Science. 1997;22:91-104.

60. Matthews CJD, Ruiz-Cooley RI, Pomerleau C, Ferguson SH. Amino acid $\delta^{15} \mathrm{~N}$ underestimation of cetacean trophic positions highlights limited understanding of isotopic fractionation in higher marine consumers. Ecology and Evolution. 2020;n/a(n/a).

61. Robbins CT, Felicetti LA, Florin ST. The impact of protein quality on stable nitrogen isotope ratio discrimination and assimilated diet estimation. Oecologia. 2010;162(3):571-9.

62. Krebs HA. The Croonian Lecture, 1963 Gluconeogenesis. Proceedings of the Royal Society of London Series B Biological Sciences. 1964;159(977):545-64.

63. Baraff LS, Clapham PJ, Mattila DK, Bowman RS. Feeding behavior of a humpback whale in lowlatitude waters. Marine Mammal Science. 1991;7(2):197-202.

64. Silva MA, Borrell A, Prieto R, Gauffier P, Bérubé M, Palsbøl PJ, Colaço A. Stable isotopes reveal winter feeding in different habitats in blue, fin and sei whales migrating through the Azores. Royal Society Open Science. 2019;6(8):181800.

560 65. Germain LR, Koch PL, Harvey J, McCarthy MD. Nitrogen isotope fractionation in amino acids from 561 harbor seals: implications for compound-specific trophic position calculations. Marine Ecology Progress Series. 2013;482:265-77.

66. Kennedy AS, Zerbini AN, Vásquez OV, Gandilhon N, Clapham PJ, Adam O. Local and migratory movements of humpback whales (Megaptera novaeangliae) satellite-tracked in the North Atlantic Ocean. Canadian Journal of Zoology. 2013;92(1):9-18.

67. Risch D, Castellote M, Clark CW, Davis GE, Dugan PJ, Hodge LEW, Kumar A, Lucke K, Mellinger DK, Nieukirk SL, et al. Seasonal migrations of North Atlantic minke whales: novel insights from large-scale passive acoustic monitoring networks. Movement Ecology. 2014;2(1):24.

68. Magozzi S, Yool A, Vander Zanden HB, Wunder MB, Trueman CN. Using ocean models to predict spatial and temporal variation in marine carbon isotopes. Ecosphere. 2017;8(5):e01763.

69. Cherry SG, Derocher AE, Hobson KA, Stirling I, Thiemann GW. Quantifying dietary pathways of proteins and lipids to tissues of a marine predator. Journal of Applied Ecology. 2011;48(2):373-81. 70. Newsome SD, Wolf N, Peters J, Fogel ML. Amino Acid $\delta^{13} C$ Analysis Shows Flexibility in the Routing of Dietary Protein and Lipids to the Tissue of an Omnivore. Integrative and Comparative Biology. 2014;54(5):890-902.

71. Borrell A, Gómez-Campos E, Aguilar A. Influence of reproduction on stable-isotope ratios: Nitrogen and carbon isotope discrimination between mothers, fetuses, and milk in the fin whale, a capital breeder. Physiological and Biochemical Zoology. 2016;89(1):41-50.

72. Carpenter-Kling T, Pistorius P, Connan M, Reisinger R, Magozzi S, Trueman C. Sensitivity of $\delta^{13} C$ values of seabird tissues to combined spatial, temporal and ecological drivers: A simulation approach. 


\section{Tables}

584 Table 1: Information on study specimens and baleen

585

\begin{tabular}{|c|c|c|c|c|c|}
\hline Species & ID & Gender & $\begin{array}{l}\text { Whale } \\
\text { length (m) }\end{array}$ & $\begin{array}{l}\text { Baleen length } \\
(\mathrm{cm})\end{array}$ & Observations \\
\hline \multirow[t]{3}{*}{ Fin whale } & 1 & Male & $18.5^{*}$ & $\begin{array}{l}28 \\
\text { (fragment) }\end{array}$ & $\begin{array}{l}\text { Juvenile bow-caught in June } 2012 \\
\text { and entered port of Rotterdam }\end{array}$ \\
\hline & 2 & Female & $12.5^{*}$ & 36.2 & $\begin{array}{l}\text { Juvenile bow-caught in August } 2013 \\
\text { and entered port of Rotterdam }\end{array}$ \\
\hline & 3 & Male & 16.5 & 49 & $\begin{array}{l}\text { Juvenile stranded in September } 2013 \\
\text { at 's Gravenzande. }\end{array}$ \\
\hline $\begin{array}{l}\text { Humpback } \\
\text { whale } \\
(\text { Johanna**) }\end{array}$ & & Female & 10.5 & 26.6 & $\begin{array}{l}\text { Adult female, stranded alive and later } \\
\text { died at the Razende Bol, sandbank } \\
\text { between Den Helder and the island of } \\
\text { Texel December } 2012 \text {. }\end{array}$ \\
\hline
\end{tabular}

\begin{tabular}{llll}
\hline Minke & Female Unknown & 18.6
\end{tabular}

whale

* Described in IJsseldijk et al. (2014)

** Described in Besseling et al. (2015) 
590 Table 2: Trophic level (TL) means for each individual. TL is a unitless measurement, $\mathrm{n}$ represents the 591 number of amino acid measurements along the length of baleen for each individual.

\begin{tabular}{|c|c|c|c|}
\hline Individual & SD & TL & $\mathrm{n}$ \\
\hline Fin Whale 1 & 0.4 & 2.7 & 10 \\
\hline Fin Whale 2 & 0.3 & 2.7 & 11 \\
\hline Fin Whale 3 & 0.5 & 2.9 & 16 \\
\hline Humpback & 0.3 & 3.4 & 12 \\
\hline Minke & 0.4 & 3.5 & 11 \\
\hline
\end{tabular}

595 Table 3: Baleen growth estimates. GAM results assessing the fluctuations of $\delta^{15} \mathrm{~N}$ in baleen plates and 596 the resulting growth estimates from these models.

\begin{tabular}{|l|c|c|c|c|c|c|c|c|}
\hline Individual & $\mathbf{n}$ & E.D.f. & $\mathbf{F}$ & Adjusted $\mathbf{R}^{\mathbf{2}}$ & $\mathbf{P}$ & Deviance explained (\%) & $\boldsymbol{\delta}^{\mathbf{1 5}} \mathbf{N}$ minima interval (cm) & Weekly growth interval (mm) \\
\hline Fin Whale 1 & 42 & 8.6 & 82 & 0.95 & $<0.001$ & 95.6 & 15.6 & 3 \\
\hline Fin Whale 2 & 35 & 8.7 & 92 & 0.96 & $<0.001$ & 96.9 & 10.4 & 2 \\
\hline Fin Whale 3 & 105 & 8.8 & 112 & 0.91 & $<0.001$ & 91.4 & $13.5,16.3,18.1$ & $2.6-3.5$ \\
\hline Humpback & 27 & 3 & 279 & 0.98 & $<0.001$ & 97.8 & NA & NA \\
5 g)tinke & 48 & 8.4 & 39 & 0.88 & $<0.001$ & 90.2 & 12.2 & 2.3 \\
\hline
\end{tabular}



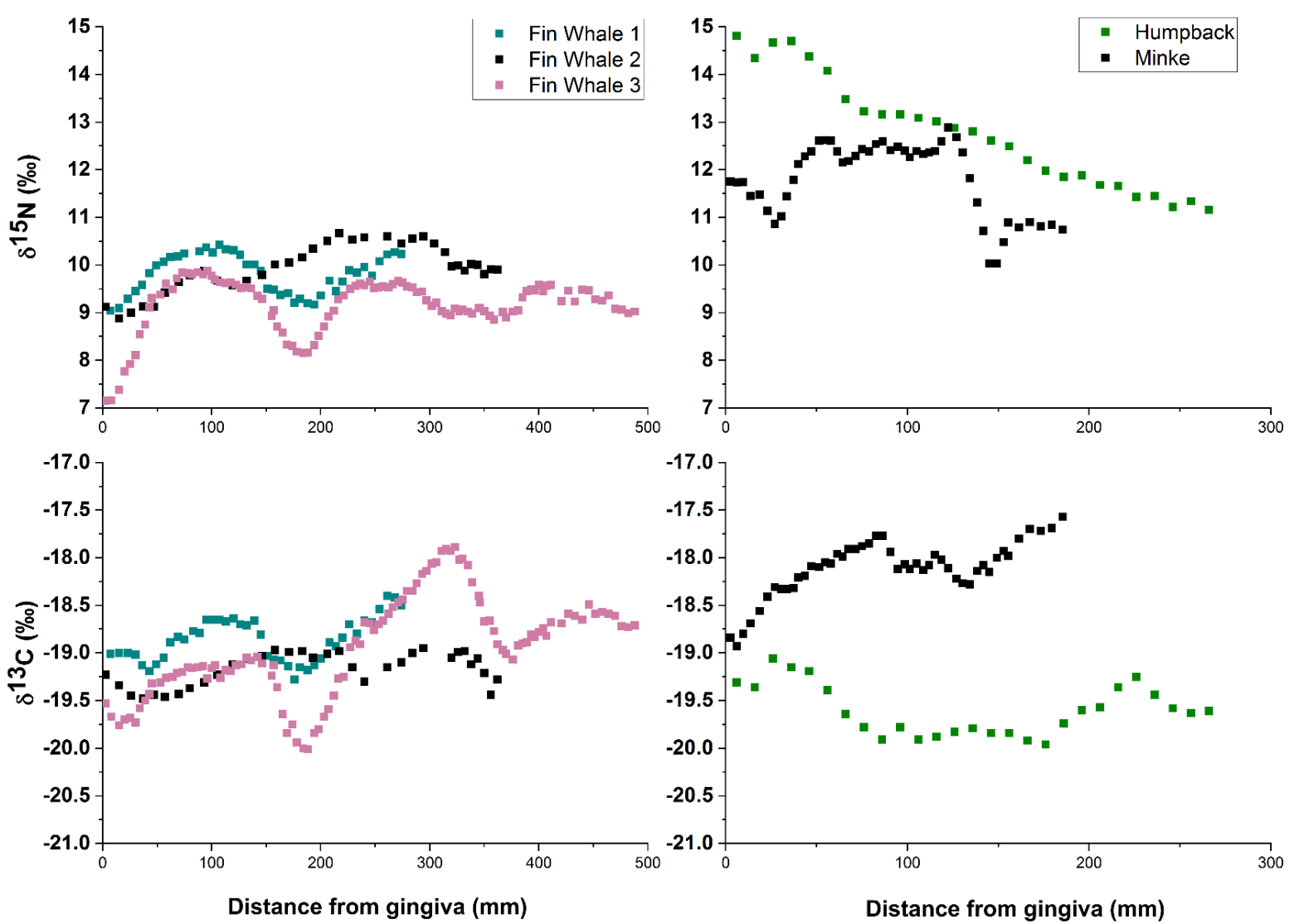

600

601 Figure 1: Bulk $\delta^{15} \mathrm{~N}$ and $\delta^{13} \mathrm{C}$ values from incrementally sampled baleen plates of 5 individual mysticetes originating from the North Atlantic. 


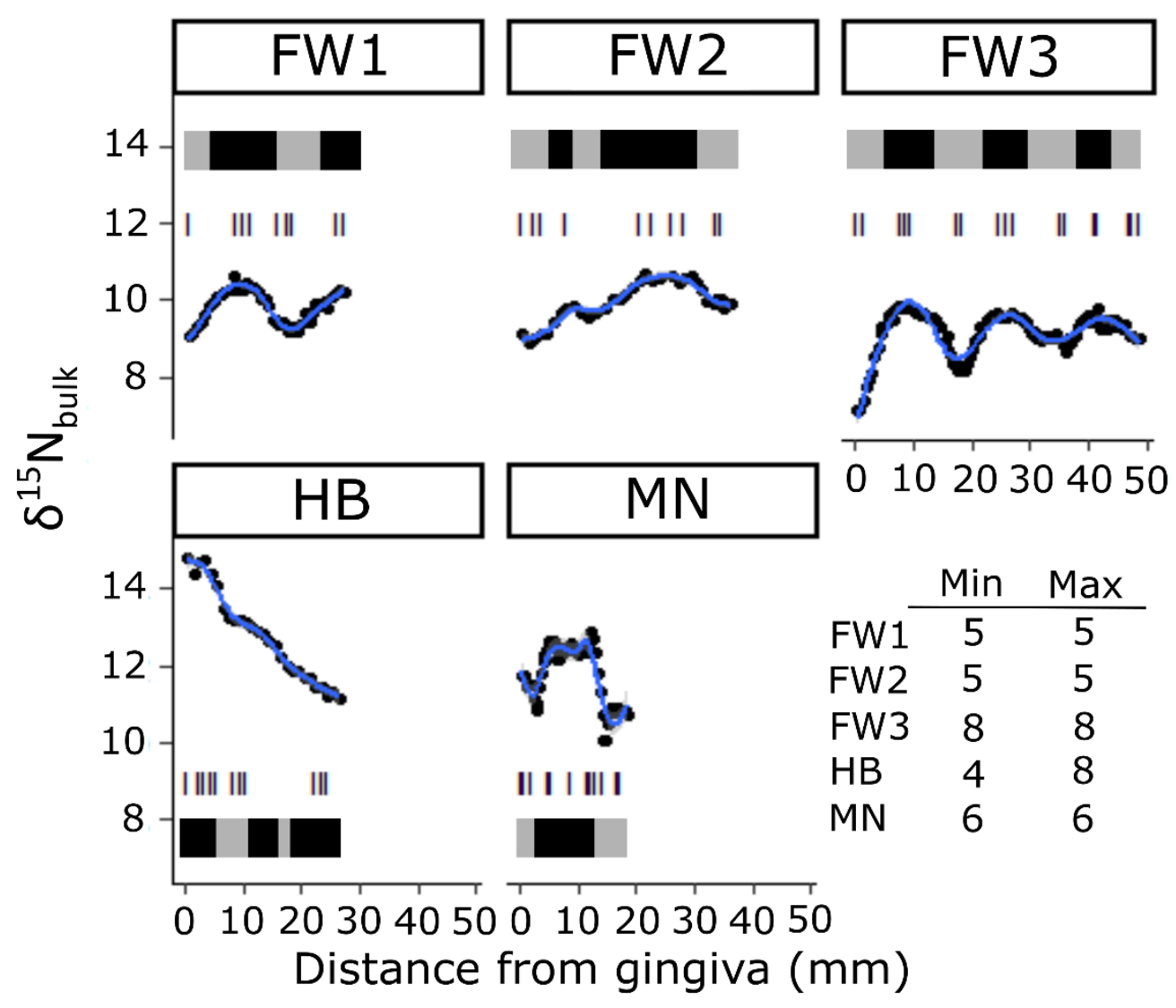

Figure 2: GAM models fit to baleen $\delta^{15} \mathrm{~N}_{\text {bulk }}$ values to identify minimum and maximum periods for $\delta^{15} \mathrm{~N}$ values in baleen for each individual (blue lines). Black shaded regions indicate periods when $\delta^{15} \mathrm{~N}$ values were above (Max) and grey shaded regions -indicate periods when $\delta^{15} \mathrm{~N}$ values were below (Min) the conditional mean for a linear regression applied to bulk $\delta^{15} \mathrm{~N}$ values. Hash marks indicate sampling intervals for determining $\delta^{15} \mathrm{~N}$ values for amino acids and the table in the bottom right panel indicates the samples located in Min and Max periods for each individual whale. 

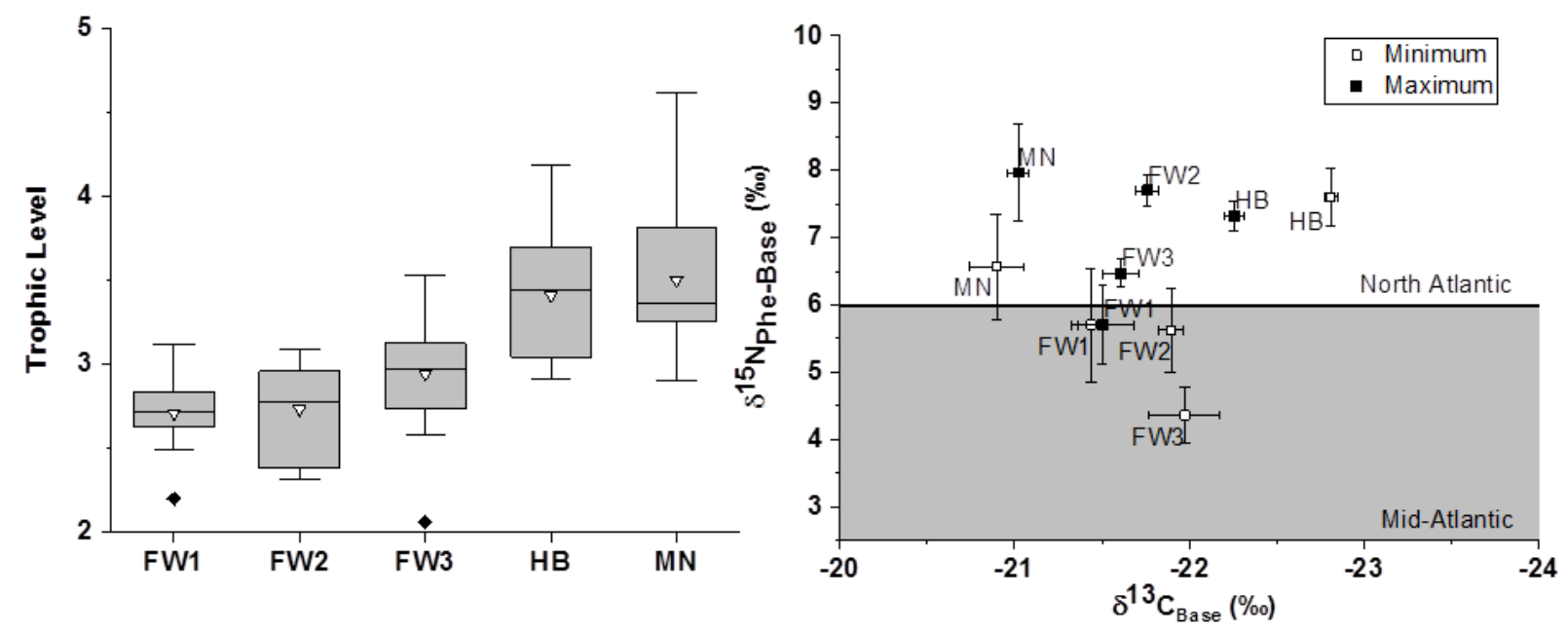

615 Figure 3: A) Trophic level estimates for each individual and B) Baleen baseline mean $\delta^{13} \mathrm{C}_{\mathrm{Base}}$ and $\delta^{15} \mathrm{~N}_{\text {Phe-Base }}$ values minimum and maximum values across the lengths of baleen for each individual; mean \pm SE. The grey shaded area indicates the $\delta^{15} \mathrm{~N}$ baseline isotope value for Mid- Atlantic (2 to 6.5\%) versus the North Atlantic (6 to 10\%) oceans (Magozzi et al 2017; Trueman et al. 2019). 

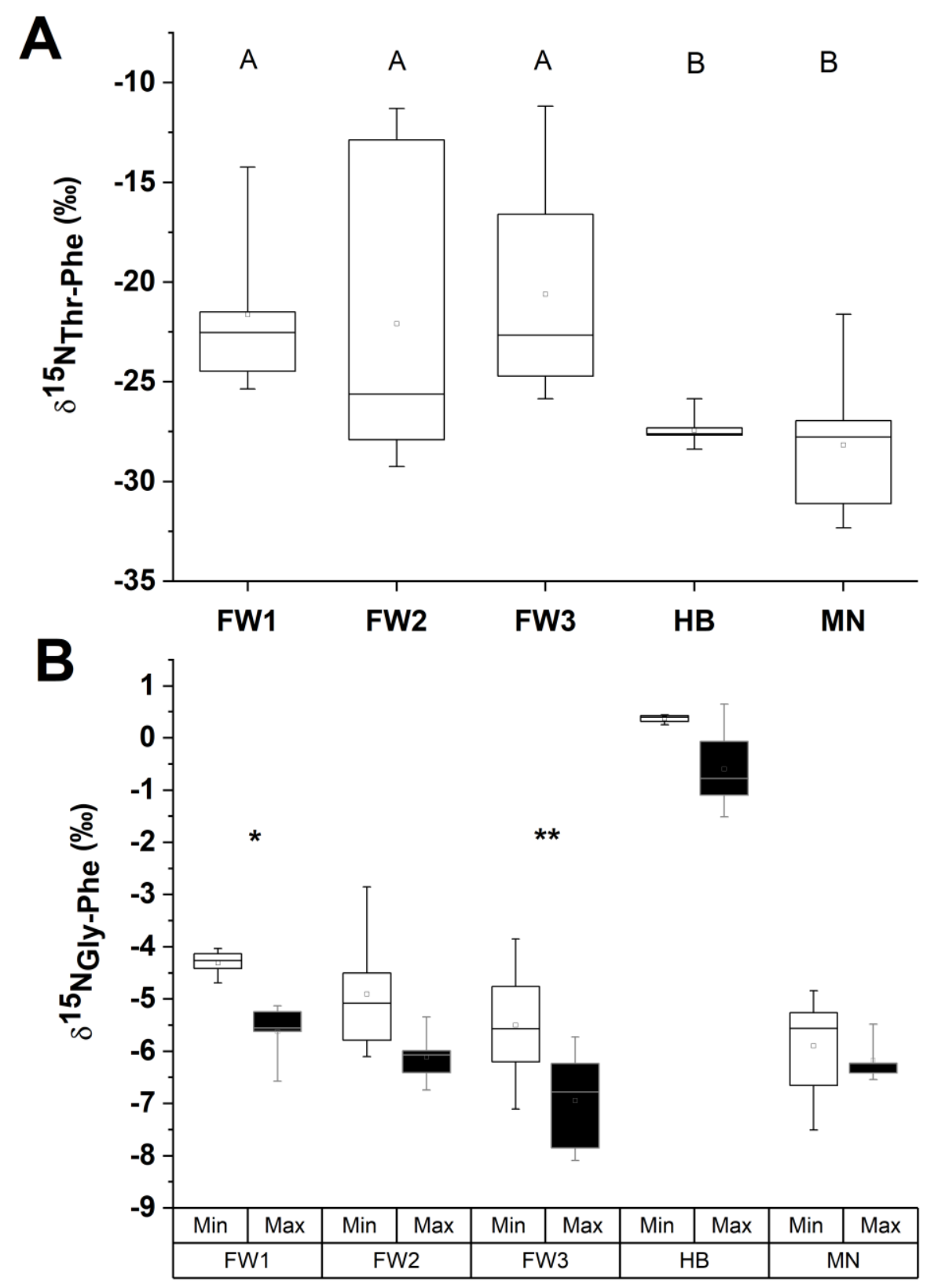

621 Figure 4: $\delta^{15} \mathrm{~N}$ for A) threonine and- B) glycine for the five mysticete individuals to assess possible

622 starvation and fasting effects between individuals and baleen periods, respectively. Both Thr and Gly have

623 had been corrected against Phe to remove underlying source AA variation. Letters indicate significant

624 differences as indicated by a post-hoc Tukey's test $(\alpha=0.05)$. For Gly, Wilcoxon ranked t-tests were used

625 to compare between baleen regions for each individual. * indicates $p=0.06$ and ** indicates $p<0.05$. 

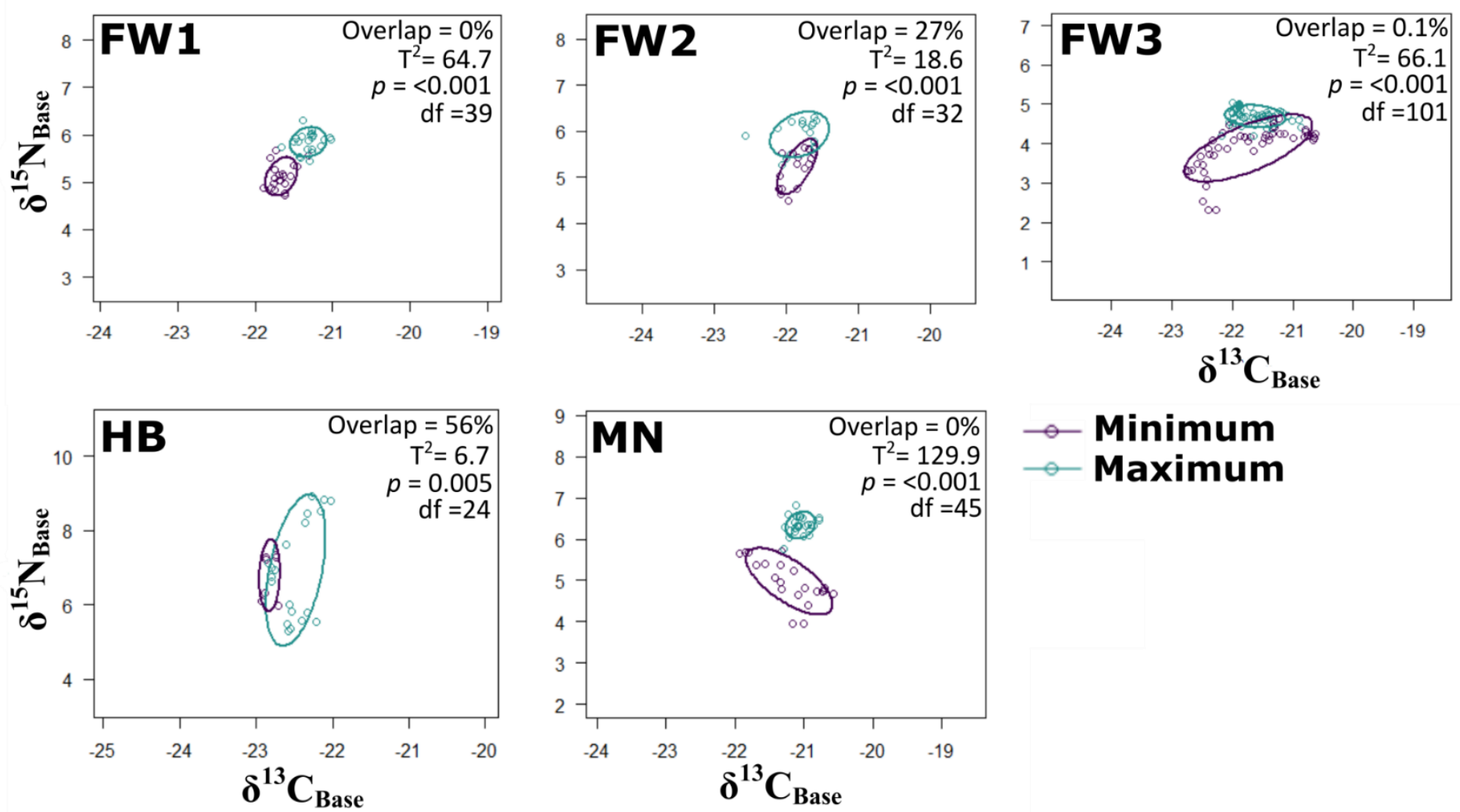

629 Figure 5: Standard ellipse areas corrected for sample size for baleen regions pooled into minimum and

630 maximum periods as determined by GAM models on $\delta^{15} \mathrm{~N}$ values for each individual. Overlap is the 631 percentage of $\%^{2}$ areal overlap between the periods. Significant $p$ values from Hotelling's $\mathrm{T}^{2}$-test indicate

632 where baleen values occupy different isotopic niches due to feeding in regions with distinct isotope 633 resource values. 
Supplemental table 1:

\begin{tabular}{|c|c|c|c|c|c|c|c|c|}
\hline \multirow[b]{2}{*}{ Species } & \multirow[b]{2}{*}{ ID } & \multirow[b]{2}{*}{$\begin{array}{c}\text { Samples } \\
\text { (n) }\end{array}$} & \multicolumn{3}{|c|}{$\delta^{13} \mathrm{C}(\%)$} & \multicolumn{3}{|c|}{$\delta^{15} \mathrm{~N}(\%)$} \\
\hline & & & $\begin{array}{l}\text { Max } \\
\text { Min }\end{array}$ & $\begin{array}{l}\text { Mean } \\
( \pm \mathrm{SD})\end{array}$ & Median & $\begin{array}{l}\text { Max } \\
\text { Min }\end{array}$ & $\begin{array}{l}\text { Mean } \\
( \pm \mathrm{SD})\end{array}$ & Median \\
\hline & 1 & 43 & $\begin{array}{l}-18.4 \\
-19.3\end{array}$ & $\begin{array}{c}-18.8 \\
(0.2)\end{array}$ & -18.9 & $\begin{array}{c}10.6 \\
9\end{array}$ & $\begin{array}{l}9.8 \\
-0.4\end{array}$ & 9.9 \\
\hline Fin whale & 2 & 36 & $\begin{array}{l}-18.9 \\
-19.5\end{array}$ & $\begin{array}{r}-19.2 \\
(0.9)\end{array}$ & -19.1 & $\begin{array}{c}10.7 \\
8.9\end{array}$ & $\begin{array}{l}9.9 \\
-0.5\end{array}$ & 10 \\
\hline & 3 & 105 & $\begin{array}{c}-17.9 \\
-20 \\
\end{array}$ & $\begin{array}{r}-18.9 \\
(0.5) \\
\end{array}$ & -18.9 & $\begin{array}{l}9.9 \\
7.1 \\
\end{array}$ & $\begin{array}{c}9.1 \\
-0.6 \\
\end{array}$ & 9.3 \\
\hline $\begin{array}{l}\text { Humpback } \\
\text { whale }\end{array}$ & & 27 & $\begin{array}{l}-19.1 \\
-19.9 \\
\end{array}$ & $\begin{array}{r}-19.6 \\
(0.2)\end{array}$ & -19.6 & $\begin{array}{l}14.8 \\
11.1 \\
\end{array}$ & $\begin{array}{l}12.8 \\
-1.1 \\
\end{array}$ & 12.8 \\
\hline Minke whale & & 48 & $\begin{array}{l}-17.6 \\
-18.9\end{array}$ & $\begin{array}{r}-18.1 \\
(0.3)\end{array}$ & -18.1 & $\begin{array}{c}12.9 \\
10\end{array}$ & $\begin{array}{l}11.8 \\
-0.8\end{array}$ & 12.2 \\
\hline
\end{tabular}

640 Supplemental Table 2: Standard ellipse areas and overlap proportions for minimum and maximum 641 baleen regions.

\begin{tabular}{|c|c|c|c|c|}
\hline Individual & $\begin{array}{c}\mathbf{S E A}_{\mathbf{c}} \\
\text { Minimum } \\
\left(\mathbf{\% o}^{\mathbf{2}}\right)\end{array}$ & $\begin{array}{c}\mathbf{S E A}_{\mathbf{c}} \\
\text { Maximum } \\
\left(\mathbf{\% o}^{\mathbf{2}}\right)\end{array}$ & $\begin{array}{c}\text { Area of } \\
\text { Overlap } \\
\left(\mathbf{\% o}^{\mathbf{2}}\right)\end{array}$ & $\begin{array}{c}\text { Overlap } \\
\text { proportion of } \\
\text { regions }\end{array}$ \\
\hline FW1 & 0.109 & 0.1 & $<0.001$ & $<0.001$ \\
\hline FW2 & 0.17 & 0.27 & 0.11 & 0.27 \\
\hline FW3 & 0.89 & 0.19 & 0.14 & 0.064 \\
HB & 0.2 & 0.98 & 0.28 & 0.56 \\
\hline MN & 0.5 & 0.09 & $<0.001$ & $<0.001$ \\
\hline
\end{tabular}

